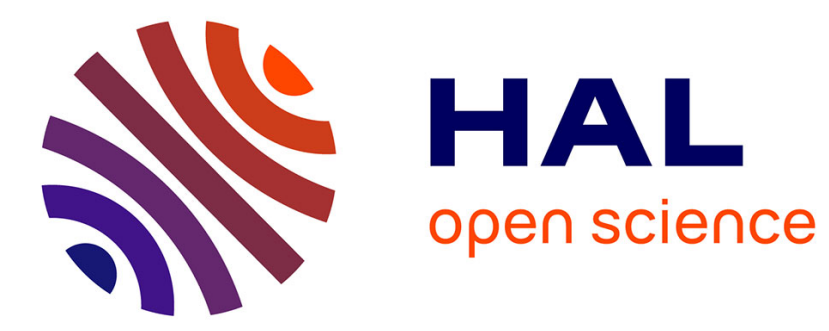

\title{
Increase of Saturation Magnetization of Ba Ferrite Films Deposited by Adding Xe Into Sputtering Gas Mixture
}

\author{
K. Noma, N. Matsushita, S. Nakagawa, M. Naoe
}

\section{To cite this version:}

K. Noma, N. Matsushita, S. Nakagawa, M. Naoe. Increase of Saturation Magnetization of Ba Ferrite Films Deposited by Adding Xe Into Sputtering Gas Mixture. Journal de Physique IV Proceedings, 1997, 07 (C1), pp.C1-487-C1-488. 10.1051/jp4:19971198 . jpa-00254848

\section{HAL Id: jpa-00254848 https://hal.science/jpa-00254848}

Submitted on 1 Jan 1997

HAL is a multi-disciplinary open access archive for the deposit and dissemination of scientific research documents, whether they are published or not. The documents may come from teaching and research institutions in France or abroad, or from public or private research centers.
L'archive ouverte pluridisciplinaire HAL, est destinée au dépôt et à la diffusion de documents scientifiques de niveau recherche, publiés ou non, émanant des établissements d'enseignement et de recherche français ou étrangers, des laboratoires publics ou privés. 


\title{
Increase of Saturation Magnetization of Ba Ferrite Films Deposited by Adding Xe Into Sputtering Gas Mixture
}

\author{
K. Noma, N. Matsushita, S. Nakagawa and M. Naoe \\ Department of Physical Electronics, Tokyo Institute of Technology, 2-12-1 O-okayama, Meguro, Tokyo \\ 152, Japan
}

\begin{abstract}
Ba ferrite thin films with well $c$-axis orientation were deposited by means of three sputtering systems and the relationships among their microstructure, magnetic characteristics and plasma parameters were discussed. It was clearly confirmed that the supp ression of heavy bombardment of energetic particles to the surface of the growing film was the most important for attaining the excellent crystallographic and magnetic characteristics.
\end{abstract}

\section{INTRODUCTION}

Since the bulk materials of a magnetoplumbite type of $\mathrm{Ba}$ ferrite $\left(\mathrm{BaM}: \mathrm{BaO} \cdot 6 \mathrm{Fe}_{2} \mathrm{O}_{3}\right)$ exhibit the magnetic characteristics such as saturation magnetization $4 \pi M_{\mathrm{s}}$ of $4.8 \mathrm{kG}$ and uniaxial anisotropy constant $K_{\mathrm{u} 1}$ of $3.3 \times 10^{5} \mathrm{~J} / \mathrm{m}^{3}$, they have been used widely as components in microwave devices as well as permanent magnets. Recently, the Ba ferrite films with well $c$-axis orientation and large $4 \pi M_{\mathrm{s}}$ are required for the applications to recording media and milliwave isolators. In this study, the plasma-free sputtering techniques were developed for the strictly control of microstructure in Ba ferrite films and then, they were able to possess the excellent crystallinity and magnetism by adjusting the plasma parameters even at the substrate temperature $T_{\mathrm{s}}$ as low as $475^{\circ} \mathrm{C}$.

\section{EXPERIMENTS}

All specimens were deposited on thermally oxidized $\mathrm{Si}\left(\mathrm{SiO}_{2} / \mathrm{Si}\right)$ wafers with the thickness of $200 \mathrm{~nm}$. The sintered ferrite plates with the compositions of $\mathrm{BaO} \cdot n \mathrm{Fe}_{2} \mathrm{O}_{3}(n=4.0,5.5,6.5)$ were used as the sputtering targets and the mixture of $\mathrm{Ar}$ and $\mathrm{O}_{2}$ (or Xe, Ar and $\mathrm{O}_{2}$ ) were used as the sputtering gas. The crystallographic and magnetic characteristics of the as-deposited films were evaluated by X-ray diffractometry, vibrating sample magnetometer and torque magnetometer, respectively. The plasma parameters such as the plasma potential $V_{\mathrm{p}}$ and the floating potential at substrate $V_{\mathrm{f}}$ were measured by Langmiur's single probe method.

\section{RESULTS AND DISCUSSION}

\subsection{Deposition with the heavy bombardment of energetic particles}

The depositions were carried out by means of the conventional RF Diode Sputtering (RFDS) apparatus using the mixture of Ar and $\mathrm{O}_{2}$ as the sputtering gas at the total pressure $p_{\text {total }}$ of $0.50 \mathrm{~Pa}$. In this case, $V_{\mathrm{p}}$ took a very large value of $+30 \mathrm{~V}$ and $V_{\mathrm{f}}$ was $-8 \mathrm{~V}$. Therefore, Ar ions bombarded the surface of the growing film at the energy of $38 \mathrm{eV}$, of which the value was large enough to cause the selective resputtering of the deposited $\mathrm{Ba}$ atoms from the film surface, and it led to the remarkable decrease of $\mathrm{Ba}$ content in the

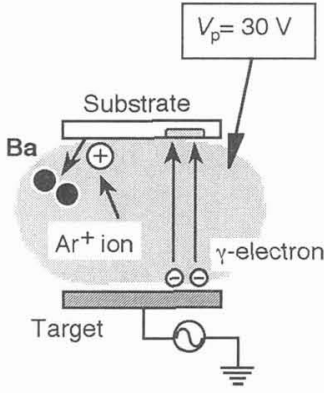

(a) RF Diode Sputtering

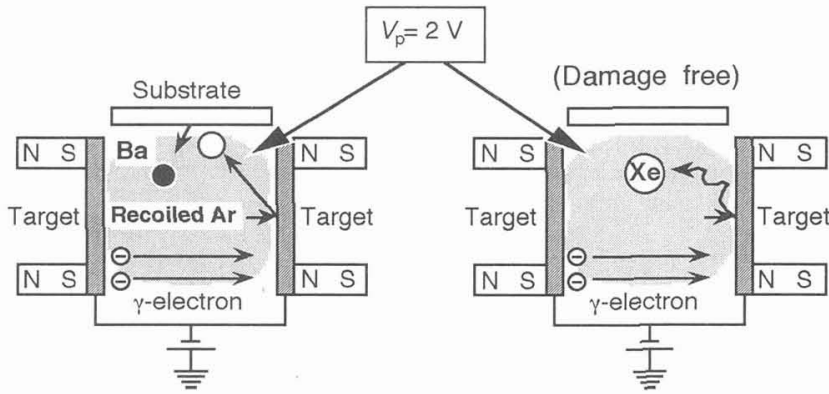

(b) Facing Targets Sputtering (with $\mathrm{Ar}+\mathrm{O}_{2}$ ) (c) Facing Targets Sputtering $\left(\right.$ with $\mathrm{Xe}+\mathrm{Ar}+\mathrm{O}_{2}$ )

Figure 1: Schematic illustrations of three sputtering systems and their plasma distributions. 

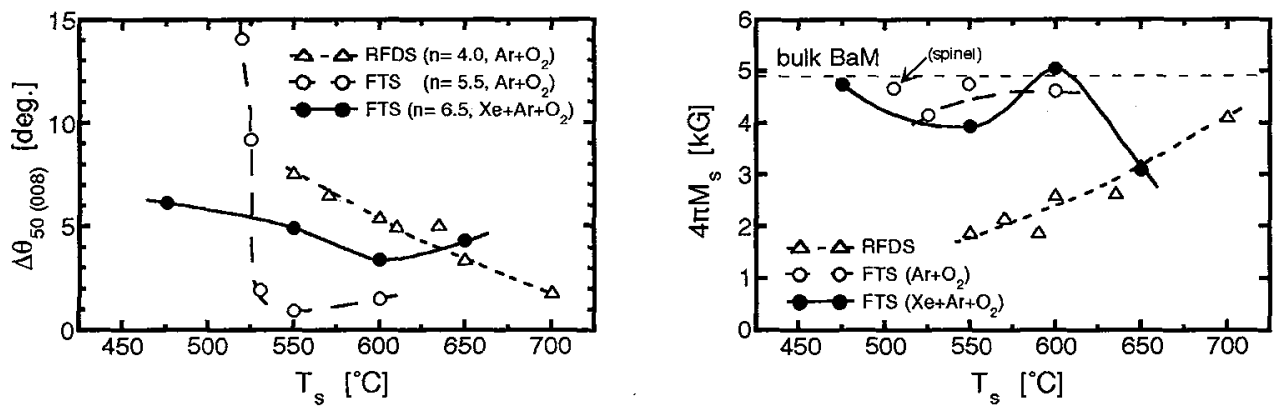

Figure 2: $T_{\mathrm{s}}$ dependences of $\Delta \theta_{50(008)}$ and $4 \pi M_{\mathrm{s}}$ for three sputtering systems.

film. In addition, the $\gamma$-electrons ejected from the sputtering target were accelerated across the sheath region and bombarded the film surface. The energy of bombarding electrons reaches to several hundreds $\mathrm{eV}$ and it caused the elevation of the substrate temperature $T_{\mathrm{s}}$ and the deconstruction of crystal. So, the Ba ferrite films with well $c$-axis orientation were deposited at $T_{\mathrm{s}}$ only in very narrow range from $620^{\circ} \mathrm{C}$ to $760^{\circ} \mathrm{C}$ using the target with a Ba-excessive composition of $\mathrm{BaO} \cdot 4.0 \mathrm{Fe}_{2} \mathrm{O}_{3}$. The (00n) dispersion angle of $\mathrm{BaM}$ crystallites $\Delta \theta_{50(008)}$ was $1.8^{\circ}$ at $T_{\mathrm{s}}$ of $700^{\circ} \mathrm{C}$. However, the saturation magnetization $4 \pi M_{\mathrm{s}}$ and the uniaxial magnetic anisotropy constant $K_{\mathrm{u} 1}$ were as comparatively small as $4.1 \mathrm{kG}$ and $1.9 \times 10^{5} \mathrm{~J} / \mathrm{m}^{3}$, respectively. These results suggest that the heavy bombardment of energetic particles during deposition may cause the resputtering of Ba atoms and the formation of thick grain boundaries with the segregated non-magnetic phase.

\subsection{Deposition with the unnegligible bombardment of recoiled Ar atoms}

In the Facing Targets Sputtering (FTS) apparatus, the DC grow plasma is confined between the two facing targets and the bombardment of charged particles such as Ar ions, $\gamma$-electrons and negative oxygen ions to the surface of the growing film was extremely reduced. While the films were deposited in FTS apparatus with the mixture of $\mathrm{Ar}$ and $\mathrm{O}_{2}$ as sputtering gas at the $p_{\text {total }}$ of $0.27 \mathrm{~Pa}, V_{\mathrm{p}}$ and $V_{\mathrm{f}}$ were as small as $2 \mathrm{Vand}-8 \mathrm{~V}$, respectively and $T_{\mathrm{s}}$ at which the films with well $c$-axis orientation were attained was as relatively low as $550^{\circ} \mathrm{C}$ and the $\Delta \theta_{50(008)}$ was as very small as $1.0^{\circ}$. However, the target composition for depositing the films with the stoichiometric composition $\left(\mathrm{BaO} \cdot 6 \mathrm{Fe}_{2} \mathrm{O}_{3}\right)$ was a little Ba-excessive $\left(\mathrm{BaO} \cdot 5.5 \mathrm{Fe}_{2} \mathrm{O}_{3}\right)$ and $4 \pi M_{\mathrm{s}}$ took the maximum value of $4.7 \mathrm{kG}$ at $T_{\mathrm{s}}$ of $600^{\circ} \mathrm{C}$. The decrease of $\mathrm{Ba}$ content in the film seemed to be caused by the unnegligible bombardment of Ar atoms recoiled from target surface and the smaller $4 \pi M_{\mathrm{s}}$ seemed to be caused by the incorporation of Ar atoms into the film body.

\subsection{Deposition without any significant bombardments}

The recoil of $\mathrm{Ar}$ atoms is intrinsic phenomena in the sputtering of $\mathrm{Ba}$ ferrite because of the large difference in atomic mass between $\mathrm{Ar}$ and $\mathrm{Ba}$ atoms and the energy of recoiled $\mathrm{Ar}$ atoms reaches to several hundreds $\mathrm{eV}$. This phenomena seemed to be sufficiently suppressed by adding $\mathrm{Xe}$ into the sputtering gas, since $\mathrm{Xe}$ and $\mathrm{Ba}$ have almost same atomic mass. $V_{\mathrm{p}}$ was maintained at the constant value of $2 \mathrm{~V}$ but $V_{\mathrm{f}}$ increased gradually from -8 to $-5 \mathrm{~V}$ and the electron temperature $T_{\mathrm{e}}$ at the center of plasma column decreased from 3.4 to $2.6 \mathrm{eV}$ with increase of the partial Xe pressure $p_{\mathrm{Xe}_{\mathrm{e}}}$. These results suggest that the addition of Xe was effective not only for suppressing the recoil of $\mathrm{Ar}$ atoms but for minimizing the ejection of the energetic species from the plasma. XRD diagrams indicated that the films deposited at $T_{\mathrm{s}}$ of $600{ }^{\circ} \mathrm{C}$ using the targets with the Fe-excessive composition of $\mathrm{BaO}^{\circ} 6.5 \mathrm{Fe} \mathrm{O}_{3}$ were composed of the crystallites of almost single phase Ba ferrite and that $4 \pi M_{\mathrm{s}}$ and $K_{\mathrm{u}}$ reached to the values of $5.1 \mathrm{kG}$ and $3.3 \times 10^{5} \mathrm{~J} / \mathrm{m}^{3}$, respectively. The significant increase of $4 \pi M_{\mathrm{s}}$ and $K_{\mathrm{u} 1}$ seemed to be correlated to the increase in the number of atomic layers in S-blocks.

In addition, the Ba ferrite films with well $c$-axis orientation and $4 \pi M_{\mathrm{s}}$ of $4.7 \mathrm{kG}$ were deposited even at $T_{\mathrm{s}}$ as low as $475^{\circ} \mathrm{C}$. The decrease of $T_{\mathrm{s}}$ was owing to the elimination of significant bombardments of energetic particles to the surface of the growing films. Such a low $T_{\mathrm{s}}$ enabled us to use the glass slides and the semiconductor sheets as substrates instead of $\mathrm{SiO}_{2} / \mathrm{Si}$ wafers.

\section{CONCLUSTON}

The microstructual and magnetic characteristics of Ba ferrite films deposited by means of three sputtering systems were investigated in detail on several sputtering parameters. It was cleared that the heavy bombardments to the surface of the growing films influence on the crystallization and the decomposition in the films and the excellent magnetic characteristics of $4 \pi M_{\mathrm{s}}$ of $4.7 \mathrm{kG}$ were attained at the optimized sputtering conditions such as the $T_{\mathrm{s}}$ of as low as $475^{\circ} \mathrm{C}$, using the targets with the Fe-excessive composition of $\mathrm{BaO} \cdot 6.5 \mathrm{Fe}_{2} \mathrm{O}_{3}$ in the FTS apparatus and the mixture of $\mathrm{Xe}, \mathrm{Ar}$ and $\mathrm{O}_{2}$ as sputtering gas.

\section{Acknowledgments}

The authors appreciate the agreement to cite the experimental results by Dr. Akimitsu Morisako of Shin-shu University.

\section{References}

[1] A. Morisako, M. Matsumoto and M. Naoe, IEEE Trans. on Magn., 22 [5] (1986) 1146-1148.

[2] M. Matsuoka, Y. Hoshi, M. Naoe and S. Yamanaka, IEEE Trans. on Magn., 18[6] (1982) 1119-1121.

[3] K. Noma, N. Matsushita, S. Nakagawa and M. Naoe, J. Appl. Phys., 79 [8] (1996) 5970-5972. 